\title{
ГІГІЄНА РУК ЯК ЗАПОРУКА БЕЗПЕКИ ЛІКУВАННЯ: СУЧАСНИЙ СТАН ПРОБЛЕМИ ТА ПЕРСПЕКТИВИ ОСВІТНЬОЇ ДІЯЛЬНОСТІ
}

\author{
${ }^{1}$ Львівський національний медичний університет імені Данила Галицького, м. Львів, Україна \\ ${ }^{2}$ Комунальне некомерційне підприємство «Комунальна міська клінічна лікарня швидкої медичної \\ допомоги», м. Львів, Україна
}

\begin{abstract}
Мета: проаналізувати сучасний стан проблематики 3 профілактики внутрішньолікарняних інфекцій із визначенням ролі, у вказаному аспекті, дотримання гігієни рук медичним персоналом. Обґрунтувати доцільність модернізації навчальних програм задля розуміння важливості та опанування практичних навичок 3 гігієни рук.

Матеріали і методи. При виконанні дослідження використано бібліографрічний та інформаційно-аналітичний методи. Науковими та регламентуючими базами $€$ інсрормаційні та робочі документи ВООЗ і Європейського регіонального бюро ВООЗ, актуальні накази та інструкції МОЗ України, електронна база даних медичних і біологічних публікацій PubMed.

Результати. Внутрішньолікарняні інфекції (нозокоміальні інфекції) виникають у 5-10 \% госпіталізованих хворих у розвинених країнах та в 20 \% пацієнтів у країнах із низьким рівнем життя. Інфрекції по-різному впливають на пацієнтів і не обмежуються лише тривалим перебуванням у лікарні, а також можуть спричинити пневмонію та смерть. Внаслідок внутрішньолікарняних інфекцій невпинно зростають фінансові витрати як для пацієнтів, так і для закладів охорони здоров'я. Іншим негативним проявом $€$ те, що ці інфекції важко піддаються лікуванню антибіотиками; зростає резистентність до багатьох антибактеріальних засобів, особливо за наявності грамнегативної мікрофрлори. Саме правильна гігієна рук серед медичних працівників може значно зменшити передачу бактеріальних збудників, а широке впровадження навчальних програм забезпечує зростання прихильності до правильної гігієни рук у закладах охорони здоров'я на 40-50 \%.

Висновки. Внутрішньолікарняні інфекції - глобальна проблема сучасної медицини і одним з ключових чинників ії поширення $€$ руки медичного персоналу. Негативним фрактором $€$ те, що ці інфекції важко піддаються лікуванню антибіотиками, відповідно, зростає резистентність до більшості антибактеріальних засобів. Правильна гігієна рук серед медичних працівників може значно зменшити передачу бактеріальних організмів. Підвищення прихильності медичного персоналу до забезпечення гігієни рук можна досягти шляхом модернізації освітніх програм, починаючи з проведення просвітницької діяльності, із вказаного питання, у студентському середовищі.
\end{abstract}

КЛЮчОВІ СЛОВА: внутрішньолікарняні інфекції; гігієна рук; медичний персонал; навчання.

У реаліях сьогодення, понад 1,4 млн пацієнтів у всьому світі можуть інфікуватися внутрішньолікарняними інфрекціями (ВЛІ). ВЛІ не тільки збільшують показники загальної захворюваності, але й пов'язані з підвищеним рівнем смертності внаслідок прямих контактів між пацієнтами та медичними працівниками. Саме зазначена форма транзиторної передачі, як вважає більшість дослідників, становить основний шлях неконтрольованого поширення патогенних мікроорганізмів. 3 огляду на це, саме гігієна рук вважається найважливішою 3 існуючих методів профрілактики ВЛІ. Метааналізи досліджень гігієни рук, проведених під контролем ВООЗ, виявили, що дотримання повного переліку гігієни рук серед медичних працівників у середньому становить лише 38,7 \% [5, 6]. Низькі показники прихильності стосовно забезпечення гігієни рук серед медиків-профресіоналів роблять вкрай актуальними всебічне впровадження подібної тематики в базові навчальні програми студентів і циклові курси професійного удосконалення лікарів та середнього медперсоналу в якості післядипломної освіти.

() В. В. Ващук, Т. П. Кирик, Г. І. Герич, М. І. Кушнірчук, 2021
Мета роботи: проаналізувати сучасний стан проблематики з профрілактики ВЛІ з визначенням ролі, у вказаному аспекті, дотримання гігієни рук медичним персоналом. Обґрунтувати доцільність модернізації навчальних програм задля розуміння важливості та опанування практичних навичок з гігієни рук.

Матеріали і методи. При виконанні дослідження використано бібліографрічний та інфрормаційно-аналітичний методи. Науковими та регламентуючими базами є інформаційні та робочі документи ВООЗ і Європейського регіонального бюро ВООЗ, актуальні накази та інструкції MO3 України, електронна база даних медичних і біологічних публікацій PubMed.

Результати дослідження та їх обговорення. За даними численних досліджень, поширення ВЛІ набуло загрозливих масштабів. Так, у провідних клініках Великої Британії у 8,2 \% пацієнтів, які перебували на стаціонарному лікуванні, виявлено ознаки ВЛІ. Останні слугували причиною до 5000 летальних випадків та додаткових витрат для системи охорони здоров'я у розмірі 930 млн фрунтів стерлінгів щорічно. При аналізі інфекційної безпеки у США було встановлено, 
що ВЛІ виникають у 5 \% пацієнтів, це, у свою чергу, збільшує видатки системи охорони здоров'я на 4,5 млрд доларів на рік. Понад 2 млн випадків ВЛІ на рік стало причиною 100000 смертельних випадків. У Канаді фріксують в середньому 220000 випадків ВЛІ щороку та 8000 пов'язаних з цим ускладненням смертей. Таким чином, кількість хворих на ВЛІ сягає, за різними оцінками, 10-70 \% від числа госпіталізованих у стаціонар, а економічний збиток, пов'язаний із ВЛІ, величезний. Зокрема, в Україні ця цифра, за найскромнішими підрахунками, сягає 5-10 млрд грн на рік.

Фахівці з інфекційного контролю і профілактики інфрекції постійно працюють над виявленням і виправленням чинників, що спричиняють появу ВЛІ. Більшість експертів вважає, що гігієна рук медперсоналу $€$ найважливішим чинником, що сприяє обмеженню поширення інфекцій, включаючи ВЛІ. Численні дослідження, проведені за останні кілька десятиліть, показали, що дотримання рекомендацій 3 гігієни рук перебуває на низькому рівні, а існуючі засоби контролю і впливу на дану ситуацію не $є$ ефрективними 3 точки зору довготривалої перспективи [9]. Експертні групи ВОО3 зазначили деякі ключові напрямки для управління та контролю ВЛІ: вдосконалення систем звітності та нагляду як на національному, так і на місцевому рівнях в рамках програми профрілактики; здійснення запобіжних заходів, особливо адекватної гігієнічної практики рук (головним чином біля ліжка пацієнтів та під час інвазивних процедур); сприяння підготовці та відповідальності медичних працівників за дотриманням гігієнічних норм [9, 11]. Було неодноразово підкреслено, що саме гігієна рук $є$ найважливішим компонентом профрілактики ВЛІ, і дотримання цієї процедури настійливо рекомендується ВООЗ $[7,12]$.

Підраховано, що миття рук з милом може врятувати мільйони життів на рік. Звичайно, це, перш за все, стосується малорозвинутих країн, 3 огляду на недосконалу інфраструктуру та проблемний доступ до базової санітарії. Під контролем ВОО3 було проведено багато кампаній для вирішення питань гігієни рук, проте мало 3 них були успішними. Тільки постійне глобальне суспільно-приватне партнерство, яке має на меті вирішити проблему дотримання гігієни рук, може дати очікувані позитивні результати [8, 10]. Задля досягнення вказаних цілей, ВОО3 щорічно проводить кампанію «SAVE LIVES: Clean Your Hands» («Збережи життя: очисти свої руки»), яка спрямована на підтримку глобального профрілю важливості гігієни рук у закладах охорони здоров'я.

Дотримання простих правил гігієни рук медиками відіграє важливу роль у збереженні життя не тільки пацієнтів (з огляду на ВлІ), але й покращує інфрекційну безпеку медичного персоналу. Варто пам'ятати, що одним 3 ключових чинників передачі збудників (у тому числі ВлІ) $є$ руки. Через руки медичний працівник може не тільки перенести інфрекцію до пацієнта, а й інфікувати себе. При контакті з руками можуть передаватися де- кілька десятків мільйонів мікроорганізмів, у тому числі патогенних і умовнопатогенних. Навіть хірургічні рукавички, за умов ігнорування базових правил гігієни рук, недостатньо ефрективні, адже мають мікропори, через які мікроорганізми з брудних рук проникають на стерильну поверхню.

У закладах охорони здоров'я оглядові кабінети необхідно облаштовувати 3 дотриманням основних правил гігієни. Зокрема, рукомийник слід локалізувати у легкодоступному місці та обладнати краном, який приводиться у дію без дотику. Поруч із рукомийником розташовують три дозатори: перший - 3 антисептиком широкого спектра дії для обробки рук; другий наповнюють рідким милом; у третьому дозаторі зберігають зволожувальний засіб для догляду за шкірою рук. Робота дозаторів активується ліктем. Всі ємності необхідно заповнювати в асептичних умовах, щоб запобігти їх забрудненню. Дозатори мийних засобів та засобів догляду за шкірою перед кожним новим заповненням необхідно ретельно очищати та дезінфікувати. Кожне місце для миття рук обладнується дозаторами одноразових рушників, серветок та ємністю для використаних засобів. На стінах доцільно розміщувати наочні навчальні матеріали: схеми та плакати з описами процедури.

Алгоритм обробки рук включає і повсякденний догляд за руками. Зокрема, нігті мають бути коротко підрізані у рівень 3 кінчиками пальців, без покриття лаком, тріщин на поверхні та додаткового декору. Перед обробленням рук потрібно зняти браслети, годинники, каблучки. Стандартна методика обробки рук проводиться відповідно до Європейського стандарту (EN 1500) та затверджена наказами Міністерства охорони здоров'я України [2, 3]. Гігієнічна обробка включає звичайне миття рук водою із милом та гігієнічну антисептику (втирання антисептика без застосування води). Звичайне миття призначене для механічного очищення рук, завдяки чому усуваються забруднення, піт, зменшується ступінь бактеріальної контамінації. Крім звичайного миття рук, стандартною процедурою впродовж робочого дня медичного працівника $€$ антисептична обробка рук без застосування води - лише втирання антисептика (найчастіше на спиртовій основі). При обробці рук необхідно враховувати наявність «критичних» ділянок, які недостатньо зволожуються антисептиком: великі пальці, кінчики пальців, міжпальцеві ділянки, нігті, нігтьові валики та піднігтьові зони. Найретельніше слід обробляти поверхні великих пальців та кінчики пальців, оскільки на них зосереджене найбільше число патогенів.

Звичайне миття рук слід проводити на початку та в кінці робочої зміни; у всіх випадках перед обробкою антисептиком, коли руки забруднені; після користування туалетом; після контакту зі збудниками ентеровірусних інфекцій. При підозрі на контакт зі споровими мікроорганізмами застосовуються алгоритми пролонгованого миття рук (щонайменше 2 хв) для механічного усунення спор. 
Гігієнічну обробку рук із застосуванням місцевих антисептиків необхідно виконувати перед входом в асептичні приміщення (передопераційна, стерилізаційні відділення); виконанням інвазійних втручань (проведення катетерів, виконання ін'єкцій); маніпуляціями, при яких існує загроза інфрікування об'єкта (приготування інфрузійних засобів); кожним прямим контактом 3 пацієнтом; переходом від інфікованої до неінорікованої ділянки тіла пацієнта; роботою зі стерильним матеріалом та інструментарієм; одяганням хірургічних рукавичок. Аналогічну обробку рук рекомендують проводити після: контакту зі забрудненими предметами, рідинами чи поверхнями; контакту 3 використаними дренажами та катетерами, чи 3 місцем їх введення; кожного контакту 3 ранами; кожного контакту з пацієнтами; зняття рукавичок; користування туалетом; після чистки носа.

Зазначені правила не є вичерпними та у конкретних ситуаціях персонал може приймати самостійне рішення. Крім того, кожний заклад охорони здоров'я уповноважений розробити свій перелік показань, який включають в план профрілактики ВЛІ, з урахуванням специфріки того чи іншого відділення. У закладах охорони здоров'я рекомендовано мати декілька антисептиків для індивідуального вибору працівниками 3 гіперчутливістю шкіри; окрім цього, потрібно дотримуватися інструкції з використання засобу [1-3].

Своєчасне і правильне дотримання чистоти рук перешкоджає поширенню інорекційних агентів, тому медичні працівники повинні бути зацікавлені у належному виконанні заходів щодо забезпечення гігієни рук. У 2016-2017 рр. у підрозділах екстреної медичної допомоги Фінляндії, Швеції, Данії було проведено емпіричне дослідження $з$ вивчення низки параметрів забезпечення гігієни рук, а саме: належне виконання заходів щодо гігієни рук згідно з прийнятими регламентами, використання бар'єрних засобів (у тому числі медичних рукавичок), дотримання загальноприйнятих гігієнічних параметрів медичних працівників (стан нігтів, волосся та носіння ювелірних виробів) [10]. При аналізі даних дослідження було встановлено, що рівень забезпечення гігієни рук склав $15 \%$ серед усіх випадків, при яких слід було застосовувати процедури забезпечення належної чистоти рук. Також було виявлено, що гігієнічні процедури до контакту 3 пацієнтом виконувалися у 3 \% випадків, перед асептичними процедурами в 2 \%, після ситуацій, пов'язаних із ризиком контакту з біологічними рідинами, у $8 \%$, після контакту з пацієнтом у $29 \%$ і в $38 \%$ - після контакту з об'єктами довкілля [8]. Дотримання вимог щодо основних гігієнічних параметрів, а саме належного стану нігтів, волосся, працівниками екстреної медичної допомоги було вищим, ніж забезпечення гігієни рук.

Рівень дотримання гігієнічної практики рук характеризується значною варіабельністю і пе- ребуває в діапазоні 3-75 \%. За даними ВООЗ, найбільш вивченим моментом $€$ гігієна рук після контакту з неживими об'єктами, включаючи медичне обладнання. Показник дотримання наведених правил становить від 28 \% (для лікарів) до $86 \%$ (для медичних сестер).

Невтішні результати зазначених досліджень вимагають подальших зусиль щодо модернізації систем безперервного навчання медичного персоналу, в тому числі з акцентом на засвоєння і відпрацювання практичних навичок забезпечення гігієни рук.

При проведенні вибіркового опитування студентів медичного та стоматологічного фракультетів медичного університету було встановлено, що більшість майбутніх лікарів добре ознайомлена з практикою гігієни рук. Зокрема, приблизно $14 \%$ студентів правильно погодилися на твердження: «традиційне миття рук (вода зі звичайним гігієнічним милом) зменшує кількість мікроорганізмів», лише 32 \% студентів правильно відповіли, що «миття рук звичайним милом замість антисептичного краще попереджує передачу ентеральних форм інфекцій». Водночас всі студенти (93 \%) погодилися про важливість навчання гігієни рук та практичного відпрацювання навичок під час проходження навчальної дисципліни «Загальна хірургія». Недостатність знань студентів щодо гігієни рук може бути покращена шляхом структурування навчальних програм, а також показовим ставленням медиків-профресіоналів до гігієни рук як зразок для майбутніх спеціалістів $[4,9,10]$.

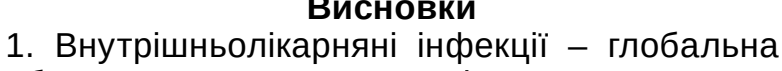
проблема сучасної медицини і одним 3 ключових чинників її поширення $€$ руки медичного персоналу. Негативним фрактором $€$ те, що ці інфекції важко піддаються лікуванню антибіотиками, відповідно, зростає резистентність до більшості антибактеріальних засобів і це, у свою чергу, стає гострою проблемою для медичних закладів (особливо за наявності грамнегативних бактеpiй).

2. Правильна гігієна рук серед медичних працівників може значно зменшити передачу бактеріальних організмів. Важливість дезінфрекції рук працівників закладів охорони здоров'я навіть не підлягає сумніву: від цього залежить не тільки здоров'я пацієнтів, а й самого медичного персоналу.

3. Підвищення прихильності медичного персоналу до забезпечення гігієни рук можна досягти шляхом модернізації освітніх програм, починаючи з проведення просвітницької діяльності, із вказаного питання, у студентському середовищі.

Перспективи подальших досліджень полягатимуть у вивченні частоти ВЛІ серед пацієнтів хірургічних відділень з високим рівнем забезпечення гігієни рук медичними працівниками. 


\section{Список літератури}

1. Про затвердження методичних рекомендацій «Епідеміологічний нагляд за інфекціями області хірургічних втручань та їх профрілактика» : наказ МОЗ України від 04.04.2008 р. № 181.

2. Про затвердження методичних рекомендацій «Хірургічна та гігієнічна обробка рук медичного персоналу» : наказ МОЗ України від 21.09.2010 р. № 798.

3. Салманов А. Г. Оптимізація забезпечення гігієни рук медичного персоналу хірургічного стаціонару / А. Г. Салманов // Український медичний часопис. - 2011. - № 2 (82). - С. 85-91.

4. Assessing hand hygiene compliance among healthcare workers in six Intensive Care Units / M. Musu, A. Lai, N. M. Mereu [et al.] // Journal of preventive medicine and hygiene. - 2017. - No. 58 (3). - P. 231-237.

5. Comparative efficacy of interventions to promote hand hygiene in hospital: systematic review and network meta-analysis / N. Luangasanatip, M. Hongsuwan, D. Limmathurotsakul [et al.] // BMJ (Clinical research ed.). - 2015. - 351. - P. 3728. https://doi.org/10.1136/bmj.h3728.

6. Compliance with hand hygiene in emergency medical services: an international observational study / H. S. Vikke, S. Vittinghus, Giebner [et al.] // Emergency medicine journal : EMJ, - 2019. - No. 36 (3). - P. 171-175. https://doi. org/10.1136/emermed-2018-207872.

7. Core competencies for infection prevention and control professionals. Geneva: World Health Organization; 2020. Licence: CC BY-NC-SA 3.0 IGO.

8. Hand Hygiene: Knowledge and Attitudes of Fourth-Year Clerkship Medical Students at Alfaisal University, College of Medicine, Riyadh, Saudi Arabia / R. Hamadah, R. Kharraz, A. Alshanqity [et al.] // Cureus. - 2015. - No. 7 (8). - P. 310. https://doi.org/10.7759/cureus.310.

9. Hospital knowledge and practice of doctors and nurses regarding hand hygiene in a survey / M. Wałaszek, M. Kołpa, A. Różańska [et al.] // Przeglad epidemiologiczny. - 2020. - No. 74 (1). - P. 119-132. https://doi.org/10.32394/pe.74.09.

10. Interventions to improve hand hygiene compliance in patient care / D. J. Gould, D. Moralejo, N. Drey, [et al.] / The Cochrane database of systematic reviews. - 2017. - Vol. 9 (9), CD005186. https://doi.org/10.1002/14651858.CD005186. pub4.

11. Knowledge and behaviour of nursing students on the prevention of healthcare associated infections / F. Brosio, P. Kuhdari, A. Stefanati [et al.] // Journal of preventive medicine and hygiene. - 2017. - No. 58 (2). - P. 99-104.

12. WHO Global Hand Hygiene Campaign 5 May 2019 - Focus on UHC // https://www.who.int/infectionprevention/ campaigns/cleanhands/5may2019/en/

\section{References}

1. (2008). MOZ Ukrainy Nakaz vid 04.04.2008 r. № 181 Pro zatverdzhennia metodychnykh rekomendatsii «Epidemiolohichnyi nahliad za infektsiyamy oblasti khirurhichnych vtruchan ta yikh profilaktyka» [MHC of Ukraine Order from 04.04.2008 No. 181 On approved of geudelunce "Epidemioloh gical interventions and their prevention"] [in Ukrainian].

2. (2010). MOZ Ukrainy Nakaz vid 21.09.2010 r. № 798 «Pro zatverdzhennia metodychnykh rekomendatsii «Khirurhichna ta hihiienichna obrobka ruk medychnoho personalu» [Ministry of Health of Ukraine Order from 21.09.2010 No. 798 On approval of guidelines "Surgical and hygienic treatment of hands of medical staff"] [in Ukrainian].

3. Salmanov, A.H. (2011). Optymizatsiya zabezpechennya hihiyeny ruk medychnoho personalu khirurhichnoho statsionaru [Optimization of hand hygiene medical personnel surgical depertment]. Ukrayinskyy medychnyy chasopys - Ukrainian Medical Journal, 2(82), 85-91 [in Ukrainian].

4. Musu, M., Lai, A., Mereu, N.M., Galletta, M., Campagna, \& Coppola, R.C. (2017). Assessing hand hygiene compliance among healthcare workers in six Intensive Care Units. Journal of Preventive Medicine and Hygiene, 58(3), $231-237$.

5. Luangasanatip, N., Hongsuwan, M., Limmathurotsakul, D., Lubell, Y., Lee, A.S., \& Cooper, B.S. (2015). Comparative efficacy of interventions to promote hand hygiene in hospital: systematic review and network meta-analysis. BMJ (Clinical research ed.), 351, 3728. https://doi.org/10.1136/bmj.h3728.

6. Vikke, H.S., Vittinghus, S., Giebner, M., Kolmos, H. J., Smith, K., Castrén, M., \& Lindström, V. (2019). Compliance with hand hygiene in emergency medical services: an international observational study. Emergency Medicine Journal : EMJ, 36(3), 171-175. https://doi.org/10.1136/emermed-2018-207872.

7. Core competencies for infection prevention and control professionals (2020). Geneva: World Health Organization; Licence: CC BY-NC-SA 3.0 IGO.

8. Hamadah, R., Kharraz, R., Alshanqity, A., AlFawaz, D., Eshaq, A. M., \& Abu-Zaid, A. (2015). Hand Hygiene: Knowledge and Attitudes of Fourth-Year Clerkship Medical Students at Alfaisal University, College of Medicine, Riyadh, Saudi Arabia. Cureus, 7(8), 310. https://doi.org/10.7759/cureus.310.

9. Wałaszek, M., Kołpa, M., Różańska, A., Jagiencarz-Starzec, B., \& Wolak, Z. (2020). Hospital knowledge and practice of doctors and nurses regarding hand hygiene in a survey. Przeglad Epidemiologiczny, 74(1), 119-132. https://doi. org/10.32394/pe.74.09.

10. Gould, D.J., Moralejo, D., Drey, N., Chudleigh, J.H., \& Taljaard, M. (2017). Interventions to improve hand hygiene compliance in patient care. The Cochrane database of Systematic Reviews, 9(9), CD005186. https://doi. org/10.1002/14651858.CD005186.pub4.

11. Brosio, F., Kuhdari, P., Stefanati, A., Sulcaj, N., Lupi, S., Guidi, E., Bergamini, M., \& Gabutti, G. (2017). Knowledge and behaviour of nursing students on the prevention of healthcare associated infections. Journal of Preventive Medicine and Hygiene, 58(2), 99-104.

12. WHO Global Hand Hygiene Campaign 5 May 2019 - Focus on UHC // https://www.who.int/infectionprevention/ campaigns/cleanhands/5may2019/en/ 
HAND HYGIENE AS A GUARANTEE OF TREATMENT SAFETY: CURRENT STATE OF THE PROBLEM AND PROSPECTS OF EDUCATIONAL ACTIVITY

V. V. Vashchuk ${ }^{1}$, T. P. Kyryk ${ }^{1}$, H. I. Herych ${ }^{2}$, M. I. Kushnirchuk ${ }^{1}$

${ }^{1}$ Danylo Halytsky Lviv National Medical University, Lviv, Ukraine

${ }^{2}$ Municipal non-profit enterprise «Lviv Municipal Emergency Hospital», Lviv, Ukraine

Purpose: to analyze the current state of the problem of prevention of nosocomial infections and determine the importance of good hand hygiene by medical staff. Justify the feasibility of modernizing curricula to understand the importance of learning practical skills for hand hygiene.

Materials and Methods. We have used bibliographic and information-analytical methods in the study. Scientific and regulatory bases are information and working documents of the WHO and the WHO European Regional Office, current orders and instructions of the Ministry of Health of Ukraine, electronic database of medical and biological publications PubMed.

Results. Nosocomial infections occur in 5-10\% of hospitalized patients in developed countries and in 20\% of patients in countries with low living standards. Infections have different effects on patients, and are not limited to prolonged hospital stays, and can cause pneumonia and death. Nosocomial infections increase financial costs for patients and healthcare facilities. These infections are difficult to treat with antibiotics, increasing resistance to many antibacterial agents, especially in the presence of gram-negative microflora. Proper hand hygiene of healthcare professionals can significantly reduce the transmission of bacterial pathogens, and the widespread implementation of training programs increases the commitment to proper hand hygiene in health care facilities by $40-50 \%$

Conclusions. Nosocomial infections are a global problem in modern medicine and a key factor in its spread is the hands of medical staff. These infections are difficult to treat with antibiotics, respectively, increasing resistance to most antibacterial agents. Proper hand hygiene among healthcare professionals can significantly reduce the transmission of bacterial organisms. Increasing the commitment of medical staff to ensure hand hygiene can be achieved by modernizing educational programs, lectures, workshops and training for students.

KEY WORDS: nosocomial infections; hand hygiene; medical personnel; education.

Рукопис надійшов до редакції 25.06.2021 p.

Відомості про авторів:

Ващук Всеволод Васильович - кандидат медичних наук, доцент кафедри загальної хірургії Львівського національного медичного університету імені Данила Галицького; тел.: +38(032) 258-74-86.

Кирик Тарас Петрович - кандидат медичних наук, доцент кафредри загальної хірургії Львівського національного медичного університету імені Данила Галицького; тел.: +38(032) 258-74-86.

Герич Гнат Ігорович - завідувач першого хірургічного відділення Комунального некомерційного підприємства «Комунальна міська клінічна лікарня швидкої медичної допомоги»; тел.: +38(032) 258-72-72.

Кушнірчук Микола Іванович - кандидат медичних наук, асистент кафедри загальної хірургії Львівського національного медичного університету імені Данила Галицького; тел.: +38(032) 258-74-86. 